\title{
KEJADIAN HIPEREMESIS GRAVIDARUM DITINJAU DARI RIWAYAT PENGGUNAAN KONTRASEPSI HORMONAL SAAT PRA KONSEPSI DI BPM KUSMAWATI SURABAYA
}

\author{
Yasi Anggasari \\ Fakultas Keperawatan dan Kebidanan \\ Universitas Nahdlatul Ulama Surabaya Jl. Smea 57 Surabaya \\ Email : yasinadya@unusa.ac.id
}

\begin{abstract}
Abstrack: Event hyperemesis gravidarum viewed from use of history when pre hormonal contraception BPM Kusmawati Surabaya. Nausea vomiting in pregnancy is a physiological state occurs in pregnant women on a trimester 1 . But still many pregnant women who experienced nausea vomiting excess accompanied the decline of appetite. The purpose of this research know the incidence of hyperemesis gravidarum seen from the history of the use of hormonal contraception during pre conception in BPM Kusmawati Surabaya. Analytic research design. The population of all pregnant women a trimester 1 visit in BPM Kusmawati Surabaya February 2015 of 22 people, large sample of 21 of respondents.Simple tekhnik random sampling, the independent variable research is the use of hormonal contraceptive and the dependent variable is hyperemesis gravidarum.Instrument of the questionnaire, data processing by means of coding, editing,tabulating and analyzed by test Chi square, with the level of kemaknaan $a=0,05$.

The results of research most ( $72.7 \%$ ) mother who use hormonal contraception had hyperemesis gravidarum. Fisher found the results of the value of statistical test excat $\rho=0,008$ significance. Significant value $\rho<\alpha$ then rejected it means there is the relationship between the use of hormonal contraceptive with hyperemesis gravidarum incident in BPM Kusmawati Surabaya.
\end{abstract}

\begin{abstract}
Abstrak: Kejadian hyperemesis gravidarum ditinjau dari riwayat penggunaan kontrasepsi hormonal saat pra konsepsi di BPM Kusmawati Surabaya. Mual muntah pada kehamilan merupakan keadaan fisiologis terjadi pada ibu hamil pada trimester 1 . Namun masih banyak ibu hamil yang mengalami mual muntah berlebih disertai penurunan nafsu makan.Tujuan penelitian ini mengetahui kejadian hiperemisis gravidarum ditinjau dari riwayat penggunaan kontrasepsi hormonal saat pra konsepsi di BPM Kusmawati Surabaya. Desain penelitian Analitik.Populasi semua ibu hamil trimester 1 yang berkunjung di BPM Kusmawati Surabaya bulan Februari 2015 sebesar 22 orang, besar sampel sebesar 21 responden. Tekhnik Simple Random Sampling, variabel Independen penelitian adalah penggunaan kontrasepsi hormonal dan variabel Dependen adalah hiperemesis gravidarum. Instrument kuesioner, pengolahan data dengan cara editing, coding, tabulating dan dianalisis dengan Uji Chi Square, dengan tingkat kemaknaan $\alpha=0,05$. Hasil penelitian sebagian besar $(72,7 \%)$ ibu yang menggunakan kontrasepsi hormonal mengalami hiperemesis gravidarum. Hasil uji statistik Excat Fisher ditemukan nilai signifikansi $\rho$ yaitu 0,008 .Nilai signifikan $\rho<\alpha$ maka $\mathrm{H}_{0}$ ditolak artinya ada pengaruh penggunaan kontrasepsi hormonal dengan kejadian hiperemesis gravidarum di BPM Kusmawati Surabaya.
\end{abstract}

Kata kunci : penggunaan kontrasepsi hormonal, hiperemesis gravidarum 


\section{PENDAHULUAN}

Mual muntah pada kehamilan merupakan keadaan yang fisiologis terjadi pada setiap ibu hamil pada trimester pertama. Mual biasanya terjadi pada pagi dan malam hari (Winkjosastro,2006). Keadaan seperti ini cukup diatasi dengan berobat jalan dan akan hilang dengan sendirinya setelah kehamilan menginjak usia kurang lebih sepuluh minggu. Namun masih banyak ibu hamil yang mengalami mual muntah berlebih yaitu lebih dari 10 kali dalam 24 jam disertai penurunan nafsu makan yang biasa disebut dengan Hiperemesis gravidarum. Keadaan seperti ini dapat mengganggu aktivitas ibu seharihari. Menurut Philip (2003), mencatat terdapat sebanyak 8,6juta ibu hamil menjadi kehilangan jam kerjanya karena masalah ini.

Komplikasi

hiperemesis gravidarum terdapat pada sekitar $60-80$ $\%$ primigravida dan pada $40-60 \%$ multigravida (Mansjoer, 2010). Gejala ini menjadi lebih berat pada 1 dari 1.000 kehamilan, namun kejadian ini akan berakibat fatal jika tidak segera ditangani (Mansjoer, 2010). Menurut Zerich, pada tahun 2011 di Jawa Timur terdapat $(8,63 \%)$ kejadian hiperemesis gravidarum ringan yang dirujuk, sedangkan di Kabupaten Sidoarjo sendiri, kejadian hiperemesis gravidarum mengalami peningkatan. Menurut data dari (Dinkes Kota Surabaya, 2013) pada tahun 2013 sebanyak (26,3\%), pada tahun 2014 sebanyak (24\%), Berdasarkan studi pendahuluan yang dilakukan di BPM Kusmawati pada bulan Januari 2015 pada ibu hamil trimester pertama yang melakukan kunjungan dengan jumlah 10 orang, menemukan ibu yang mengalami hiperemesis gravidarum sebanyak 7 orang (70\%). Dari 7 orang yang mengalami hiperemesis gravidarum, 5 orang $(71 \%)$ sebelumnya merupakan akseptor hormonal, dan 2 orang (29\%) merupakan akseptor IUD.

Faktor penyebab terjadinya Hiperemesis Gravidarum pada ibu hamil, antara lain keletihan, janinwanita, mual muntah pada kehamilan sebelumnya, penggunaan pil kontrasepsi saat prakonsepsi, mual premenstruasi, stress cemas, dan takut (Tiran, 2009). Mual dan muntah selama kehamilan biasanya disebabkan oleh perubahan dalam sistem endokrin yang terjadi selama kehamilan, terutama disebabkan karena tingginya fluktuasi HCG (Human Chorionic Gonadotropin), khususnya periode mual muntah gestasional karena meningkatnya kadar hormon estrogen dan HCG (Human Chorionic Gonadotropin) dalam serum (Tiran,2009). Pengaruh Fisiologik kenaikan hormon ini belum jelas, mungkin karena sistem saraf pusat atau pengosongan lambung yang berkurang. Pada umumnya wanita dapat menyesuaikan dengan keadaan ini, meskipun demikian gejala mual dan muntah yang berat dapat berlangsung sampai empat bulan.

Penggunaan kontrasepsi hormonal mempengaruhi terjadinya mual muntah.Estrogen dan progesterone telah lama terlibat dalam etiologi mual muntah, karena kadarnya yang terus meningkat.Penggunaan kontrasepsi hormonal diduga mempengaruhi penyerapan vitamin B6 dari makanan sehingga dapat memperparah mual muntah. Terdapat juga peningkatan insidensi mual muntah pada wanita yang telah mengalami beberapa kali kehamilan karena kedua hormone tersebut memiliki kadar yang lebih besar dibanding dengan wanita yang pertama kali hamil.

Hiperemesis gravidarum adalah salah satu penyulit kehamilan, walaupun angka kejadiannya tidak cukup banyak namun dampak klinis dan sosial dapat menjadi suatu masalah besar bagi ibu dan janinnya serta akan mengganggu aktivitas ibu sehari-hari. Ibu hamil bisa mengalami dehidrasi yang dapat berakibat fatal jika tidak ditangani dengan baik. Hiperemesis gravidarum yang menetap akan mengalami dehidrasi yang berakibat pada kerusakan organ hati dan ginjal. Pada 
keadaan yang parah perlu perawatan khusus karena hiperemesis gravidarum ini menyebabkan perubahan bahkan gangguan keseimbangan cairan dan elektroli, defisiensi nutrisi, gangguan liver. Sementara pertumbuhan janin akan terganggu akibat ibu kekurangan nutrisi kemudian akan berdampak pada kematian (Fika, 2007).

Pencegahan terhadap hiperemesis gravidarum perlu dilaksanakan diantaranya dengan jalan menghilangkan atau mengatasi kecemasan ibu hamil dengan memberikan penjelasan tentang kehamilan dan persalinan sebagai proses yang fisiologis, memberikan keyakinan bahwa mual dan muntah merupakan gejala yang fisiologis pada kehamilan muda dan akan hilang setelah kehamilan empat bulan, memberikan kenyamanan psikologis akan sangat membantu ibu hamil dalam mengatasi mual muntah yang dialami.Namun jika memperburuk gejala yang ada menyebabkan ibu mengalami dehidrasi, anjurkan ibu untuk bed rest total dengan asupan nutrisi dan cairan tetap terjaga, ibu makan sedikit tapi sering, hindari makan berminyak dan berbau, akan lebih baik jika makanan dihidangkan dalam keadaan panas atau sangat dingin (Prawirohardjo, 2009). Berdasarkan latar belakang diatas maka penulis tertarik untuk melakukan penelitian tentang pengaruh penggunan kontrasepsi hormonal dengan kejadian hiperemesis gravidarum

\section{METODE}

Jenis penelitian yang digunakan yaitu analitik, dengan Pendekatan Cross Sectional karena peneliti melakukan pengamatan data variabel independen dan variabel dependen secara bersamaan dalam waktu yang sama..

Populasi dalam penelitian ini adalah semua ibu hamil trimester pertama yang melakukan kunjungan di BPM Kusmawati Surabaya pada bulan Februari 2015 sebesar 22 orang.Sampel dalam penelitian ini adalah sebagian ibu hamil trimester pertama yang berkunjung ke BPM Kusmawati Surabaya pada bulan Februari 2015. Besar sampel yang digunakan pada penelitian ini ditentukan dengan menggunakan rumus (Nursalam, 2015) :

$$
\text { Cara pengambilan sampel }
$$

menggunakan teknik Probability

Sampling, dengan cara Simple Random Sampling, yaitu dengan membuat undian menurut nomor urutan kunjungan pada seluruh ibu hamil trimester pertama pada bulan Februari 2015. Kemudian dilakukan pengocokan dan diambil sebanyak 21 responden untuk dijadikan sampel penelitian.

Instrument yang digunakan dalam pengumpulan data berupa lembar kuesioner untuk pengumpulan data tentang hiperemesis gravidarum dan penggunaan kontrasepsi hormonal. Data yang dikumpulkan meliputi data primer, yaitu penggunaan kontrasepsi hormonal dengan kejadian hiperemesis gravidarum pada ibu

\section{HASIL DAN PEMBAHASAN}

a. Hasil

1. Karakteristik responden menurut usia Karakteristik responden menurut usia dapat dikategorikan menjadi , terlalu muda (<20 tahun), reproduksi (20-35 tahun), terlalu tua ( 235 tahun).

Tabel 1. Distribusi frekuensi responden berdasarkan usia pada ibu hamil trimester 1 yang berkunjung di BPM Kusmawati pada bulan Februari 2015

\begin{tabular}{llll}
\hline No & $\begin{array}{l}\text { Usia } \\
\text { (tahun) }\end{array}$ & Frekuensi & $\begin{array}{l}\text { Persentase } \\
(\%)\end{array}$ \\
\hline 1 & $<20$ & 0 & 0 \\
2 & $20-35$ & 20 & 95,2 \\
3 & $\geq 35$ & 1 & 4,8 \\
\hline Total & & 21 & 100 \\
\hline
\end{tabular}

Sumber : Data Primer, 2015 
Berdasarkan tabel 1. dapat dilihat bahwa dari 21 responden hampir seluruhnya (95,2\%) ibu berusia 20-35tahun.

2. Karakteristik responden berdasarkan pekerjaan

Tabel 2. Distribusi frekuensi responden berdasarkan pekerjaan pada ibu hamil trimester 1 yang berkunjung di BPM Kusmawati Surabaya pada bulan Februari 2015

\begin{tabular}{llll}
\hline No & Pekerjaan & Frekuensi & $\begin{array}{l}\text { Persentase } \\
(\%)\end{array}$ \\
\hline 1 & Tidak & 17 & 81,0 \\
2 & bekerja & 4 & 19,0 \\
\hline Total & & 21 & 100 \\
\hline
\end{tabular}

Sumber : Data Primer, 2015

Berdasarkan tabel 2. dapat dilihat bahwa dari 21 responden hampir seluruhnya $(80,96 \%)$ ibu tidak bekerja.

3. Karakteristik responden berdasarkan jumlah kehamilan

Tabel 3. Distribusi frekuensi responden berdasarkan paritas pada ibu hamil trimester 1 yang berkunjung di BPM Kusmawati pada bulan Februari 2015

\begin{tabular}{llll}
\hline No & $\begin{array}{l}\text { Jumlah } \\
\text { kehamilan }\end{array}$ & Frekuensi & $\begin{array}{l}\text { Persentase } \\
(\%)\end{array}$ \\
\hline 1 & Hamil ke-1 & 7 & 33,33 \\
2 & Hamil ke-2 & 10 & 47,62 \\
3 & Hamil ke-3 & 4 & 19,05 \\
\hline Total & & 21 & 100 \\
\hline
\end{tabular}

Sumber : Data Primer, 2015

Berdasarkan tabel 3. dapat dilihat bahwa dari 21 responden hampir setengahnya $(47,62 \%)$ ibu pada kehamilan ke-2.

4. Karakteristik responden berdasarkan mual muntah pada kehamilan sebelumnya

Tabel 4. Distribusi frekuensi responden berdasarkan mual muntah pada kehamilan sebelumnya pada ibu hamil trimester 1 yang berkunjung di BPM Kusmawati pada bulan Februari 2015

\begin{tabular}{llll}
\hline No & $\begin{array}{l}\text { Riwayat } \\
\text { mual } \\
\text { muntah }\end{array}$ & Frekuensi & $\begin{array}{l}\text { Persentase } \\
(\%)\end{array}$ \\
\hline 1 & Tidak & 4 & 28,6 \\
2 & Ya & 10 & 71,4 \\
\hline Total & \multicolumn{3}{c}{ Sumber : Data Primer, 2015 }
\end{tabular}

Berdasarkan tabel 4. dapat dilihat bahwa dari 14 responden sebagian besar $(71,4 \%)$ ibu mengalami mual muntah pada kehamilan sebelumnya.

5. Karakteristik responden berdasarkan mual premenstruasi

Tabel 5 Distribusi frekuensi responden berdasarkan mual premenstruasi pada ibu hamil trimester 1 yang berkunjung di BPM Kusmawati pada bulan Februari 2015

\begin{tabular}{llll}
\hline No & $\begin{array}{l}\text { Mual } \\
\text { premenstruasi }\end{array}$ & Frekuensi & $\begin{array}{l}\text { Persentase } \\
(\%)\end{array}$ \\
\hline 1 & Tidak & 20 & 95,2 \\
2 & Ya & 1 & 4,8 \\
\hline \multicolumn{2}{l}{ Total } & 21 & 100 \\
\hline \multicolumn{4}{r}{ Sumber : Data Primer, 2015 }
\end{tabular}

Berdasarkan tabel 5. dapat dilihat bahwa dari 21 responden hampir seluruhnya $(95,24 \%)$ ibu tidak mengalami mual premenstruasi.

6. Karakteristik responden berdasarkan pemakaian kontrasepsi hormonal

Tabel 6. Distribusi frekuensi responden berdasarkan pemakaian kontrasepsi hormonal pada ibu hamil trimester 1 yang berkunjung di BPM Kusmawati pada bulan Februari 2015

\begin{tabular}{llll}
\hline No & $\begin{array}{l}\text { Kontrasepsi } \\
\text { Hormonal }\end{array}$ & Frekuensi & $\begin{array}{l}\text { Persentase } \\
(\%)\end{array}$ \\
\hline 1 & Tidak & 10 & 47,6 \\
2 & Ya & 11 & 52,4 \\
\hline Total & 21 & 100 \\
\hline
\end{tabular}

Sumber : Data Primer, 2015

Berdasarkan tabel 5.6 dapat dilihat bahwa dari 21 responden sebagian besar $(52,4 \%)$ ibu memakai kontrasepsi Hormonal 
7. Karakteristik responden berdasarkan alasan menggunakan kontrasepsi hormonal

Tabel 7. Distribusi frekuensi responden berdasarkan alasan menggunakan kontrasepsi hormonal pada ibu hamil trimester 1 yang berkunjung di BPM Kusmawati pada bulan Februari 2015

\begin{tabular}{llll}
\hline No & $\begin{array}{l}\text { Alasan } \\
\text { menggunakan } \\
\text { hormonal }\end{array}$ & Frekuensi & $\begin{array}{l}\text { Persentase } \\
(\%)\end{array}$ \\
\hline 1 & $\begin{array}{l}\text { Mengatur } \\
\text { menstruasi }\end{array}$ & 3 & 27,3 \\
2 & $\begin{array}{l}\text { Kurangnya } \\
\text { waktu ke nakes }\end{array}$ & 2 & 18,2 \\
3 & Biaya & 6 & 54,5 \\
\hline \multicolumn{2}{l}{ Total } & 11 & 100 \\
\hline
\end{tabular}

Sumber : Data Primer, 2015

Berdasarkan tabel 7. dapat dilihat bahwa dari 11 responden yang mengunakan kontrasepsi hormonal sebagian besar $(54,5 \%)$ beralasan karena faktor biaya.

8. Karakteristik responden berdasarkan kejadian Hiperemesis Gravidarum

Tabel 8. Distribusi frekuensi responden berdasarkan kejadian hiperemesis gravidarum pada sebagian ibu hamil trimester 1 yang berkunjung di BPM Kusmawati pada bulan Februari 2015

\begin{tabular}{llll}
\hline No & $\begin{array}{l}\text { Hiperemesis } \\
\text { Gravidarum }\end{array}$ & Frekuensi & $\begin{array}{l}\text { Persentase } \\
(\%)\end{array}$ \\
\hline 1 & Tidak & 12 & 57,1 \\
2 & Ya & 9 & 42,9 \\
\hline Total & 21 & 100 \\
\hline
\end{tabular}

Sumber : Data Primer, 2015

Berdasarkan tabel 8 dapat dilihat bahwa dari 21 responden sebagian besar $(57,1 \%)$ ibu tidak mengalami hiperemesis gravidarum.

9. Pengaruh antara penggunaan kontrasepsi hormonal dengan kejadian Hiperemesis Gravidarum

Tabel 9. Tabulasi silang $2 \times 2$ antara penggunaan kontrasepsi hormonal dengan kejadian hiperemesis gravidarum di BPM

Kusmawati pada bulan Februari 2015

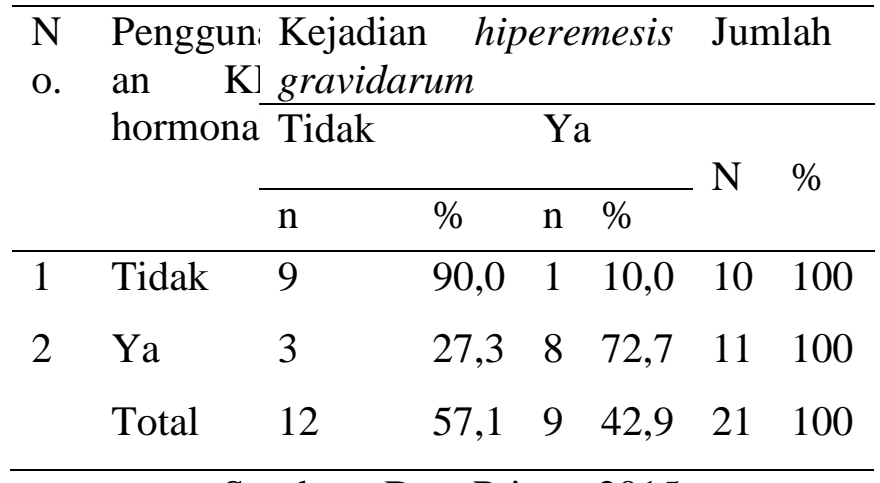

Sumber : Data Primer 2015

Berdasarkan tabel 9 menunjukkan bahwa dari 10 responden yang tidak menggunakan kontrasepsi hormonal hampir seluruhnya $(90,0 \%)$ tidak mengalami hiperemesis gravidarum, sementara dari 11 responden yang menggunakan kontrasepsi hormonal sebagian besar $(72,7 \%)$ mengalami hiperemesis gravidarum.

Hasil Uji Chi Square didapatkan ada 2 tabel dengan nilai cell kurang dari 5 sehingga syarat Uji Chi Square tidak terpenuhi, untuk itu digunakan Uji Excat Fisher ditemukan nilai signifikansi $\rho$ yaitu 0,008. Nilai signifikan $\rho<\alpha$ maka $\mathrm{H}_{0}$ ditolak artinya ada pengaruh penggunaan kontrasepsi hormonal terhadap kejadian hiperemesis gravidarum di BPM Kusmawati Surabaya.

\section{b. Pembahasan}

Berdasarkan hasil penelitian di BPM Kusmawati Surabaya pada tabel 6 diketahui bahwa dari 21 ibu hamil, sebagian besar $(52,4 \%)$ menggunakan kontrasepsi hormonal sebelum kehamilan. Banyak ibu yang memilih menggunakan kontrasepsi hormonal dengan alasan hormonal mempunyai efektivitas yang tinggi, tidak bergantung pada petugas kesehatan, sedikit efek samping, siklus haid menjadi teratur, serta kesuburan akan cepat kembali setelah penggunaan kontrasepsi dihentikan. Menurut Affandi (2011), terdapat beberapa keuntungan dalam menggunakan kontrasepsi pil antara 
lain memiliki efektivitas yang tinggi, risiko terhadap kesehatan sangat kecil, tidak mengganggu hubungan seksual, siklus haid menjadi teratur, banyaknya darah haid berkurang (mencegah anemia), dapat digunakan jangka panjang selama perempuan masih ingin menggunakannya untuk mencegah kehamilan, dapat digunakan sejak usia remaja hingga menopause, mudah dihentikan setiap saat, kesuburan segera kembali setelah penggunaan dihentikan.

Berdasarkan tabel 7 didapatkan bahwa dari 11 responden yang menggunakan hormonal, sebagian besar (54,5\%) memilih menggunakan hormonal dengan alasan biaya. Pada sebagian besar ibu hamil di BPM Kusmawati saat pra konsepsi mereka menggunakan pil microgynon dengan harga rata-rata 12.500 rupiah serta suntik $\mathrm{KB}$, dengan harga yang relatif murah dan mempunyai keefektivan yang tinggi akan sangat mempengaruhi ibu untuk menggunakan KB hormonal. Glasier (2006) berpendapat bahwa biaya dari suatu strategi keluarga berencana mencakup biaya metode itu sendiri, waktu yang dikorbankan wanita dan petugas, serta biaya tak langsung lainnya, termasuk ongkos berkunjung ke klinik.

Selain biaya, pengendalian terhadap gangguan menstruasi juga menjadi alasan ibu menggunakan kontrasepsi pil. Dilihat dari tabel 7 dari 11 responden yang menggunakan kontrasepsi pil hampir setengahnya $(27,3 \%)$ menyatakan bahwa dengan menggunakan kontrasepsi pil siklus haid akan menjadi teratur. Banyak ibu yang menggunakan kontrasepsi lain mengeluh siklus haidnya tidak teratur. Hal tersebut yang mempengaruhi ibu untuk beralih menggunakan kontrasepsi pil.Hal ini sesuai dengan pendapat Glasier (2006) bahwa beberapa kontrasepsi hormonal dapat mengurangi perdarahan menstruasi, dan dapat membantu menghilangkan rasa nyeri dan tidak nyaman akibat menstruasi yang tidak teratur atau menyakitkan.

Faktor biaya dan teraturnya siklus haid, kontak dengan petugas kesehatan juga menjadi alasan ibu menggunakan kontrasepsi hormonal. Dapat dilihat pada tabel 7 dari 11 responden yang menggunakan kontrasepsi hormonal khususnya pil, sebagaian kecil $(18,2 \%)$ diantaranya beranggapan bahwa penggunaan pil dapat meminimalkan kontak dengan petugas kesehatan. Bagi ibu yang mempunyai aktivitas padat akan sangat sedikit waktu untuk berkunjung ke petugas kesehatan. Dengan menggunakan pil mereka dapat memperoleh kontrasepsi pil di apotek terdekat.Menurut Glasier (2006) mereka yang sering bepergian mungkin memilih metode yang tidak mengharuskan mereka berkonsultasi secara teratur dengan petugas.

Berdasarkan tabel 8 didapatkan data bahwa dari $21 \mathrm{ibu}$ hamil yang berkunjung pada bulan Desember 2015, sebagian besar $(57,1 \%)$ tidak mengalami hiperemesis gravidarum. Hiperemesis gravidarum merupakan keadaan dimana ibu hamil mengalami mual muntah berlebih disertai dengan penurunan nafsu makan sehingga menyebabkan ibu mengalami dehidrasi. Menurut Varney (2006) Hiperemesis gravidarum adalah mual dan muntah yang berlebihan selama kehamilan karena intensitasnya melebihi muntah normal lebih dari 10 kali dalam 24 jam dan berlangsung selama kehamilan trimester pertama. Penyebab hiperemesis gravidarum belum diketahui scara pasti. Namun menurut Tiran (2009) mengemukakan tentang beberapa faktor predisposisi penyebab hiperemesis gravidarum yaitu keletihan, janin wanita, mual muntah pada kehamilan sebelumnya, penggunaan kontrasepsi hormonal saat pra konsepsi, mual premenstruasi, stress, cemas, dan takut.

Pada tabel 5 dari 21 responden hampir seluruhnya $(95,2 \%)$ tidak mengalami mual premestruasi. Sangat jarang sekali ibu hamil pada saat premenstruasi mengalami mual.Fakta medis yang diketahui adalah bahwa kedua hormon yaitu estrogen dan progesterone berkaitan erat dengan mual. Jika kadar kedua hormon tersebut tidak 
seimbang maka akan menyebabkan mual. Hal ini sesuai dengan pendapat Glasier (2009) wanita yang sebelumnya mengalami mual dan pusing saat menggunakan kontrasepsi hormonal atau selama fase pramenstruasi lebih rentan mengalami mual dan muntah gestasional.

Berdasarkan tabel 4 dapat dilihat dari 21 ibu hamil yang berkunjung di BPM Kusmawati, sebagian besar $(71,4 \%)$ mengalami mual muntah pada kehamilan sebelumnya. Ibu hamil yang mengalami mual muntah pada kehamilan sebelumnya cenderung akan mengalami mual muntah pada kehamilan selanjutnya. Hal ini diakibatkan karna stressor ibu yang merasa bahwa dirinya akan mengalami mual muntah yang sama dengan kehamilan yang lalu. Selain itu peningkatan kadar hormon estrogen dan progesterone akan lebih besar pada kehamilan berikutnya. Pernyataan tersebut juga diutarakan oleh Tiran (2009) bahwa terdapat juga peningkatan insidensi mual dan muntah pada wanita yang telah mengalami beberapa kali kehamilan, karena kedua hormon tersebut memiliki kadar yang lebih besar dibandingkan wanita yang baru pertama kali hamil yang mendukung adanya pengaruh estrogen dan progesterone sebagai penyebab rasa mual dan muntah.

Berdasarkan hasil uji Chi SquareTest dengan tingkat kemaknaan $\alpha=0,05$. Kemudian dianalisis dengan bantuan perhitungan SPSS 16.0 for windows, Maka hasil Uji Chi Square didapatkan ada 2 tabel dengan nilai cell kurang dari 5 sehingga terdapat syarat Uji Chi Square yang tidak terpenuhi, untuk itu digunakan Uji Excat Fisher ditemukan nilai signifikansi $\rho$ yaitu 0,008 . Nilai signifikan $\rho<\alpha$ maka $\mathrm{H}_{0}$ ditolak artinya ada pengaruh penggunaan kontrasepsi hormonal dengan kejadian hiperemesis gravidarum di BPM Kusmawati Surabaya.

Pada tabel 9 tentang tabulasi silang antara penggunaan kontrasepsi hormonal dengan kejadian hiperemesis gravidarum, menunjukkan bahwa dari 10 responden yang tidak menggunakan kontrasepsi hormonal hampir seluruhnya (90,0\%) tidak mengalami hiperemesis gravidarum, hal ini dikarenakan ibu memiliki kadar esterogen dan progesterone yang lebih rendah dan kemudian mereka juga mampu beradaptasi dengan kondisi kehamilannya, sedangkan dari 11 responden yang menggunakan kontrasepsi pil sebagian besar $(72,7 \%)$ mengalami hiperemesis gravidarum diduga karena adanya penumpukan kadar estrogen dan progesterone. Ibu yang mengalami hiperemesis gravidarum telah berhenti menggunakan kontrasepsi hormonal selama antara 1-7 bulan.Ketika pemakaian hormonal dihentikan, sistem hormon dalam tubuh tidak serta merta pulih dan kembali normal seperti sebelum menggunakan.Kembalinya kesuburan ditandai dengan normalnya siklus haid, dan dalam hal ini setiap individu memerlukan waktu yang berbeda antara 112 bulan, jadi tidak seketika.Setiap wanita dalam tubuhnya memiliki kedua hormon tersebut kemudian ditambah dengan sisa hormon dari penggunaan kontrasepsi hormanal yang dapat mepengaruhi penyerapan vitamin B6.Sehingga dapat disimpulkan bahwa penggunaan kontrasepsi hormonal saat prakonsepsi dapat menyebabkan keparahan mual muntah.Menurut Tiran (2009) Estrogen dan progesterone telah lama terlibat dalam etiologi mual muntah, karena kadarnya yang terus meningkat.Penggunaan kontrasepsi hormonal diduga mempengaruhi terjadinya mual muntah yang dapat mempengaruhi penyerapan vitamin B6 dari makanan sehingga dapat memperparah mual muntah.

\section{SIMPULAN}

Berdasarkan hasil penelitian yang telah dilakukan, dapat disimpulkan sebagai berikut :

1. Ibu hamil trimester pertama di BPM Kusmawati Surabaya hampir seluruhnya menggunakan kontrasepsi hormonal sebelum kehamilan. 
2. Ibu hamil trimester pertama di BPM Kusmawati Surabaya sebagian besar tidak mengalami hiperemesis gravidarum.

3. Ada pengaruh antara penggunaan kontrasepsi hormonal saat pra konsepsi dengan kejadian hiperemesis gravidarum.

\section{DAFTAR PUSTAKA}

Affandi, Biran (2011). Buku Panduan Praktis Pelayanan Kontrasepsi. Jakarta, YBPSP.

Alimul, Aziz (2007). Metode Penelitian Kebidanan Teknis Analisis Data.Yogyakarta : Salemba Medika

Almatsier, S (2003). Prinsip Dasar Ilmu Gizi. Jakarta, PT. Gramedia Pustaka Utama

Arikunto, S (2006). Prosedur Penelitian Suatu Pendekatan Praktek. Jakarta, Bhineka Cipta.

Dinkes Sidoarjo (2013). Profil Dinas Kesehatan Kota Sidoarjo, 2013. Sidoarjo

Glasier, Anna (2006). Keluarga Berencana \& Kesehatan Reproduksi. Jakarta, EGC.

Mansjoer, Arif (2007). Kapita Selekta Kedokteran Jilid 1. Jakarta, Aesculaplus.

Mansjoer(2010).http://savitriyuliana0/2015 /06/makalah-hiperemesis-gravidarum. diakses tanggal 16 februari 2015.

Manuaba, IBG (2007). Pengantar Kuliah Obstetric. Jakarta, EGC.

Manuaba, IBG (2005). Ilmu Kebidanan, Penyakit Kandungan dan Keluarga Berencana Untuk Pendidikan Bidan. Jakarta, EGC.

Nursalam (2008).Konsep \& Penerapan Metodologi Penelitian Ilmu Keperawatan Pedoman Skripsi, Thesis, \&Instrument Penelitian Keperawatan. Jakarta, Salemba Medika.

Prawirohardjo, Sarwono (2006). Ilmu Kebidanan. Jakarta, YBPSP.

Roestam, Mochtar (2011). Sinopsis Obstetri : Obstetris Fisiologi, Obstetri Patologi. Jakarta, EGC.
Saifuddin, Abdul Barri (2006). Pelayanan Kesehatan Maternal \& Neonatal. Jakarta, YBPSP.

Tiran, Denise (2009). Mual \& Muntah Kehamilan. Jakarta, EGC.

Varney, Hellen (2006). Buku Ajar Asuhan Kebidanan. Jakarta, EGC.

Winkjosastro, Hanifa (2005). Ilmu Kebidanan. Jakarta, EGC.

Zerich (2011). Hiperemesis Gravidarum : http//wordpress.com. Diakses tanggal 16 februari 2015. 